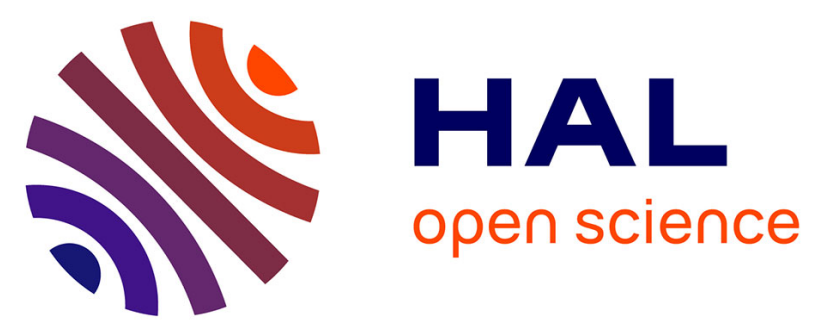

\title{
Evaluation of the performance of different cleaning treatments in reducing microbial contamination of poultry transport crates
}

Vivien Allen, Colin H Burton, David J Wilkinson, Robin T Whyte, Jillian Anne Harris, Mary Howell, David B Tinker

\section{To cite this version:}

Vivien Allen, Colin H Burton, David J Wilkinson, Robin T Whyte, Jillian Anne Harris, et al.. Evaluation of the performance of different cleaning treatments in reducing microbial contamination of poultry transport crates. British Poultry Science, 2008, 49 (03), pp.233-240. 10.1080/00071660802094206 . hal-00545331

\section{HAL Id: hal-00545331 \\ https://hal.science/hal-00545331}

Submitted on 10 Dec 2010

HAL is a multi-disciplinary open access archive for the deposit and dissemination of scientific research documents, whether they are published or not. The documents may come from teaching and research institutions in France or abroad, or from public or private research centers.
L'archive ouverte pluridisciplinaire $\mathbf{H A L}$, est destinée au dépôt et à la diffusion de documents scientifiques de niveau recherche, publiés ou non, émanant des établissements d'enseignement et de recherche français ou étrangers, des laboratoires publics ou privés. 


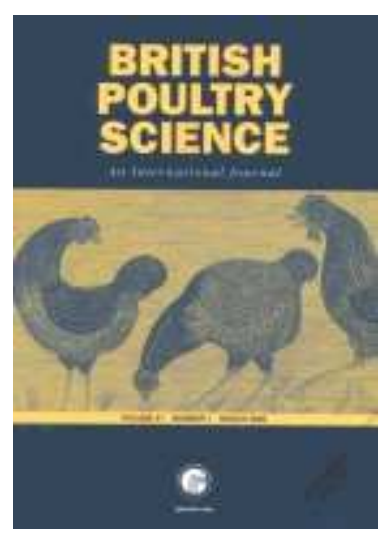

\section{Evaluation of the performance of different cleaning treatments in reducing microbial contamination of poultry transport crates}

\begin{tabular}{|r|l|}
\hline Journal: & British Poultry Science \\
\hline Manuscript ID: & CBPS-2007-263.R1 \\
\hline Manuscript Type: & Original Manuscript \\
\hline Date Submitted by the & $17-J a n-2008$ \\
\hline Author: & $\begin{array}{l}\text { Allen, Vivien; University of Bristol, Clinical Veterinary Science } \\
\text { Burton, Colin; CEMAGREF } \\
\text { Wilkinson, David; Formerly Silsoe Research Institute } \\
\text { Whyte, Robin; Formerly Silsoe Research Institute } \\
\text { Harris, Jillian; University of Bristol, Clinical Veterinary Science } \\
\text { Howell, Mary; Food Standards Agency, Veterinary Public Health } \\
\text { Tinker, David; David Tinker \& Associates Ltd }\end{array}$ \\
\hline Keywords: & Broilers, transport crates, cleaning \\
\hline \multicolumn{2}{|c}{} \\
\hline
\end{tabular}

\section{(s) ScholarONE \\ Manuscript Central}


1 Evaluation of the performance of different cleaning treatments in reducing

2 microbial contamination of poultry transport crates

3

4

5 V. M. ALLEN, C. H. BURTON ${ }^{1}$, D.J. WILKINSON ${ }^{2}$, R. T. WHYTE ${ }^{2}$,

J. A. HARRIS, M. HOWELL ${ }^{3}$ AND $_{v}$ D. B. TINKER ${ }^{4}$

Department of Clinical Veterinary Science, University of Bristol, Langford, North Somerset, England, ${ }^{1}$ CEMAGREF, Groupement de Rennes, 17, Avenue de Cucillé RENNES. France, ${ }^{2}$ Formerly Silsoe Research Institute, Silsoe, Bedfordshire, ${ }^{3}$ Food Standards Agency, Aviation House, 125 Kingsway, London, ${ }^{4}$ David Tinker \& Associates Ltd, 17 Chandos Road, Ampthill, Bedfordshire, England

\section{Running head: CLEANING POULTRY TRANSPORT CRATES}

Correspondence to Dr Allen, Department of Clinical Veterinary Science, University of Bristol, Langford, North Somerset, BS40 5DU, UK.

Email: viv.allen@bris.ac.uk

Accepted for publication 27th January 2008

Abstract 1. The present systems for cleaning the plastic crates (drawers) used to transport live poultry to the processing plant are known to be inadequate for removing microbial contamination.

2. To investigate possible improvements, a mobile experimental rig was constructed and operated in the lairage of a poultry processing plant. The cleaning rig could simulate the conditions of commercial cleaning systems and utilise freshly-emptied crates from the processing plant. 
29 3. The aim of the study was to improve cleaning by enhancing the removal of

30 adherent organic material on the crates and by reducing microbial contamination by at

31 least $4 \log _{10}$ units.

32 4. Trials showed that the most effective treatments against Campylobacter were

33 either (a) the combination of soaking at $55^{\circ} \mathrm{C}$, brushing for $90 \mathrm{~s}$, washing for $15 \mathrm{~s}$ at

$3460^{\circ} \mathrm{C}$, followed by the application of disinfectant (Virkon $\mathrm{S}$ in this study) or (b) the

35 use of ultrasound $(4 \mathrm{~kW})$ at $65^{\circ} \mathrm{C}$ for $3-6 \mathrm{~min}$, with or without mechanical brushing

36 of crates.

37 5. Both of these treatments also achieved a $4-\log _{10}$ reduction or more in the counts of

38 Enterobacteriaceae but were less effective in reducing aerobic plate counts.

Formatted: Font: Italic

6. It was noted that there was little correlation between the visual assessment of crate

40 cleanliness and microbiological counts.

41 7. It was concluded that the demonstrated enhanced cleaning could contribute

42 significantly to overall hygiene control in poultrymeat production.

43

\section{INTRODUCTION}

45 The plastic crates in which live poultry are commonly transported from the farm to 46 the processing plant are known to be a source of contamination and cross47 contamination with zoonotic pathogens such as Salmonella and Campylobacter spp.

48 (Tinker et al., 2005). The problem arises primarily because most of the crate49 cleaning systems used commercially do not consistently remove microbial 50 contaminants before the crates are re-used (Humphrey and Allen, 2002). The 51 potential role of contaminated crates in spreading Salmonella has been highlighted in 52 Canada by Rigby et al. $(1980 a, b)$ and also reported in other countries in relation to

53 either Salmonella or Campylobacter (Jacobs-Reitsma and Bolder (1998), Bailey et al. 
(2001), Corry et al. (2002), Slader et al. (2002) and Allen et al. (2008)) thus showing

55 that the situation has remained unchanged for at least 20 years. Factors responsible

56 for the poor performance of commercial cleaning systems include the practice of

57 recycling most of the wash-water, which becomes increasingly loaded with microbes

58 and organic debris. However, in the absence of effective disinfection, it is likely that,

59 even with the use of fresh water throughout the process, current cleaning systems

60 would still have only a limited impact on microbial contamination of the crates

61 (Burton et al., 2004).

Because it is evident that improvements in crate cleaning are needed, the present study was carried out to evaluate a number of possible treatment options.

64 These were aimed at removing any adherent organic material present and the removal and /or destruction of microbial contaminants on the crate surface. The trials were based around a mobile experimental rig in which the washing conditions simulated

67 those of a commercial cleaning system and which utilised freshly-emptied crates from

68 a poultry processing plant.

\section{$71 \quad$ Test rig}

72 The stages typically involved in crate cleaning are (i) the inversion of the crate, (ii)

73 pre-washing, (iii) soaking, (iv) final wash, (v) crate reversion, and (vi) disinfection.

74 For experimental purposes, a mobile crate-cleaning rig was designed and constructed

75 for independent operation in the lairage/crate washing area of a poultry processing

76 plant. This approach (a) avoided any disruption of the commercial cleaning process,

77 (b) made use of the actual soiled crates as soon as the birds had been removed and (c)

78 allowed a wide range of possible treatments to be evaluated after the crates had been 
79 inverted to remove any loose organic debris. The rig is shown in Figure 1 and its

80 basic features illustrated in Figure 2. With the use of water spray-jets and a soak

81 tank, it was possible to simulate various commercial conditions using cleaning water

82 from the adjacent commercial plant that was naturally contaminated with organic

83 matter from the crate-cleaning operation. Alternatively, the rig could use clean water

84 and included a water heater. The rig operated in a batch-wise manner, cleaning

85 individual crates for specified times corresponding to the measured residence periods

86 in the commercial system.

\section{Crate treatments}

88 Specific treatments studied in conjunction with the rig were as follows.

89 Use of detergent

90 For some trials, a detergent was added to the soak tank at the beginning of the trial to

91 facilitate the cleaning process. This was a low-foam, caustic product (Spectak G:

92 Johnson Diversey, Northampton, UK) and it was incorporated in the water at a

93 concentration of $0.1 \%(\mathrm{v} / \mathrm{v})$.

94 Crate disinfection

95 Chemical disinfection of washed crates was carried out with a hand-held spray that 96 delivered a measured amount of disinfectant solution to each crate. The disinfectant 97 chosen was Virkon S (Dupont Animal Health Solutions, Sudbury, Suffolk, UK) as an 98 example of a product commonly used in the industry. Applications were specified as $99250 \mathrm{ml}$ of $0.5 \%(\mathrm{v} / \mathrm{v}), 500 \mathrm{ml}$ of $1 \%(\mathrm{v} / \mathrm{v})$ or $500 \mathrm{ml}$ of a $2 \%(\mathrm{v} / \mathrm{v})$ solution.

\section{Water removal}

101 In order to remove the residual wash-water that could carry a high microbial load, the 102 vibrating tray rig was used in conjunction with the washing trials. An alternative rig 
103 104

105 106

107

108 109

110

111

112

113

114

124 Two different methods were used as follows.

125 Swab method

126 Four large cotton-wool swabs with wooden shafts (MW 104J, Medical Wire,

127 Corsham, Wilts, UK) were moistened with Maximum Recovery Diluent (MRD, 
146 From serial, 10-fold sample dilutions in MRD, $100 \mu \mathrm{l}$ amounts of each were used to

147 inoculate in duplicate, Plate Count Agar (PCA, Oxoid CM0325) and Violet Red Bile

148 Glucose Agar (VRBGA, Oxoid CM 0485). Plates were incubated at either $30^{\circ} \mathrm{C}$ for

$14948 \mathrm{~h}(\mathrm{PCA})$ or $37^{\circ} \mathrm{C}$ for $24 \mathrm{~h}(\mathrm{VRBGA})$ and the colonies counted. Characteristically,

150 Enterobacteriaceae appear as round, purple colonies $1-2 \mathrm{~mm}$ in diameter and

151 surrounded by purple haloes. As recommended by the media manufacturer, however,

CM 733, Oxoid, Basingstoke, Hants, UK) and each was used to sample one quarter of the interior base-area of the crate. Swabbing was carried out in horizontal, vertical and diagonal directions, and all 4 swabs were pooled in 10 $\mathrm{ml}$ of MRD.

Sponge method

Using aseptic precautions, a sterile sponge of 103 x 185 x $5.8 \mathrm{~mm}$ (cat. No. 95000087, Spongyl 87, Spontex Professionel, Neuilly-Sur-Seine, France) was wetted with a small amount of liquid from $100 \mathrm{ml}$ of MRD and transferred to a sterile plastic bag. When required, the sponge was removed and used to swab the interior base of the crate in horizontal, vertical and diagonal directions from bottom left to top right. The sponge was then returned to the bag and the remainder of the MRD added. Using both hands, the bag was squeezed 60 times to release microbial cells into the diluent. Finally, the sponge was wrung out aseptically by hand and the resultant suspension transferred to a $100 \mathrm{ml}$ screw-capped container. For both sampling methods, samples were transported to the laboratory in a cool box held at around $1^{\circ} \mathrm{C}$ using ice packs and were examined within $12 \mathrm{~h}$.

Formatted: Font: Italic

Formatted: Font: Italic

all red colonies were counted as presumptive Enterobacteriaceae. 
153 154

155

156

157

158

159

160

161

162

163

164

165

Enumeration of Campylobacter spp.

Sample dilutions $(100 \mu \mathrm{l})$ were used to inoculate modified charcoal cefoperazone desoxycholate agar, which comprised Campylobacter Blood-free Selective Agar Base (Oxoid, CM 739) and Campylobacter Selective Supplement (Oxoid, SR 155). Plates were incubated at $42^{\circ} \mathrm{C}$ for $48 \mathrm{~h}$ under micro-aerobic conditions from gas-generating packs (Oxoid, CN 0035A), after which colonies were counted. Standard confirmatory tests included a positive oxidase reaction, microscopical appearance of Gram-strained preparations and failure to grow in air at $25^{\circ} \mathrm{C}$. Some colonies were confirmed as Campylobacter by a latex agglutination method (Campylobacter Test Kit: Oxoid, DR 0150M).

\section{Visual assessment of organic debris}

To determine the effect of residual organic debris on the microbiological condition of the crates, tests were carried out on crates cleaned and sampled at the processing plant. The tests involved 12 crates, each of which was also sampled by swabbing the internal surface of the base and obtaining an APC and a count of Enterobacteriaceae, as described above. Crates were then scored visually for the total amount of organic debris in grams on each of three parts of the crate: (i) the interior of the base; (ii) the sides, both inside and out, and (iii) the underside. The organic matter could not be completely removed from the crate, so the amount present was estimated on the basis that one heaped $5 \mathrm{ml}$ teaspoon of debris was found to weigh approximately $2 \mathrm{~g}$.

\section{Statistical analysis}


178

179

180

181

182

183

184

185

186

187

188

189

190

191

192

193

194

195

196

197 198

199

200

201

202

\section{RESULTS}

\section{Selection of processing plant}

Before starting the trials, it was necessary to ensure that the processing plant used in conjunction with the test rig was not atypical with respect to the cleaning of transport crates. Therefore, a comparison was made of plants belonging to three different companies and tests were carried out on crates before and after cleaning to determine $\mathrm{APC}$ and incidence of Enterobacteriaceae and Campylobacter. For this purpose, 12 crates were taken on each occasion and sampled by the swab method. The results shown in Table 1 indicate that the three plants were comparable, especially in relation to APC, but varied markedly with regard to Campylobacter, which would have been influenced by the colonisation status of the flocks processed that day. In the two cases where crates were tested before and after the cleaning process, there was little effect of cleaning on APC or Enterobacteriaceae counts. The plant selected for the study (Plant B) had sufficient space to accommodate the test rig alongside the commercial crate-cleaning system, with easy access to the supply of used crates and necessary services

Deleted: 
203 204

different approaches, the aim being to reduce microbial contamination by at least 4 $\log _{10}$ units. This value was chosen as it is the standard often used to assess effective cleaning of food contact surfaces. The first series of trials covered variations in current commercial practices for soaking and washing crates and is designated TA in Table 3. The second approach (TB) was concerned with the removal of contaminated process water from the crates and the third (TC) was devoted to different options for crate disinfection, including the use of a chemical disinfectant (Virkon S), steam, UV light and ultrasonic treatment. The final series of trials, TD covered more vigorous cleaning systems, which involved brushing, use of detergent and increased amounts of disinfectant, and a second wash at the end of the process. The results given in Table 3 are presented in each case as the changes in mean counts on PCA and VRBGA, respectively, relative to those obtained for the uncleaned control crates.

In general, most of the treatments had only a relatively small effect $\left(<2 \log _{10}\right.$ units) in reducing crate contamination and, in some cases, the mean counts were slightly higher after treatment, showing the absence of any obvious kill or removal of microbes. However, some treatments resulted in reductions of at least $3-5 \log _{10}$ units. These were mostly related to process options including brushing, soaking or washing at $63^{\circ} \mathrm{C}$ and using an increased amount of disinfectant. Therefore, a second series of trials were based on selected combinations of the more successful treatments.

\section{Testing of selected best treatment combinations}

The results obtained with the most effective treatment combinations are shown in Figure $3 \mathrm{a}, \mathrm{b}$ and c for APC, Enterobacteriaceae and Campylobacter respectively. 
246 Soiled transport crates are not easy to clean and disinfect properly under the

247 conditions used currently for operating commercial systems. Part of the reason for

248 this lies with the design of the plastic crates themselves. There are many niches

249 present that can trap organic debris and microbes, and, during long-term use, surfaces

when compared with the control group (uncleaned crates). The treatments options investigated included a combination of soaking at $55^{\circ} \mathrm{C}$, brushing for $90 \mathrm{~s}$, washing for $15 \mathrm{~s}$ in water at $60^{\circ} \mathrm{C}$, followed by the application of disinfectant, or the use of ultrasound at $65^{\circ} \mathrm{C}$ for $3-6$ min, either with or without mechanical brushing of the crates, Treatment 2 included a double stage of hot soaking, brushing and hot washing. The same treatments were less effective with respect to APC and Enterobacteriaceae, but still achieved at least a 4- $\log _{10}$ reduction in the latter $(P<$ may become scratched and suffer other minor damage that adds to the problem.

251 Furthermore, there is rapid development of a biofilm, which is a thin layer of adherent 
253

(Burton et al., 2004). Other contributory factors relate to the cleaning process itself, which is often constrained by the space available at the processing plant. One consequence of this is that the residence time of each crate in the washing cycle is greatly limited. Although 'best practices' have been identified from these studies to improve present crate-cleaning procedures (Tinker et al., 2005), these are unlikely to have sufficient effect on microbial contamination to make the cleaning process a critical control point in the processing operation, as proposed by Slader et al. (2002). Thus, the present study set out to evaluate a number of possible treatments beyond normal factory conditions that might achieve a significant reduction in microbial contamination. For that purpose, it was necessary to perform the trials in a controlled manner and under conditions that resembled those used commercially. The use of an experimental rig, situated in a processing plant, has avoided the apparent limitations of trials carried out in a purely laboratory setting (Carr et al., 1999).

From the practical viewpoint, complete sterilisation of the crates is not a feasible objective and a reduction of at least $4 \log _{10}$ units in microbial contamination was considered to be an acceptable target. To achieve this, however, crates would need to be as clean as possible before the application of a disinfectant, since any residual soiling would be expected to neutralise the applied chemical and thus reduce treatment efficacy, as indicated by Corry et al. (2002) and Slader et al. (2002) from observations on commercial practices, and borne out in the present study. Thus, the treatments studied here have included a number of measures aimed at facilitating the removal of organic debris from the crates. Of these, only mechanical brushing and ultrasonic treatment would require any significant technological changes in the cleaning process. Although the application of ultrasound was aimed primarily at loosening attached debris, it appeared to have a synergistic effect with heat in killing a 
278

279

proportion of the microbes present and would merit further investigation, in the context of crate cleaning.

The most effective treatments studied here differed from that recommended by Ramesh et al. (2003), in which transport containers with galvanised frames and fibreglass floors were immersed for $2 \mathrm{~min}$ in $1000 \mathrm{mg} / \mathrm{l}$ of sodium hypochlorite at $70^{\circ} \mathrm{C}$. This combination was found to eliminate coliform bacteria and Salmonella, when containers were treated in a prototype cleaning system, but it is likely to be less effective when part of the wash water is recycled, due to the build-up of organic matter and the large amounts of chemical. Partial recycling of wash water is a common practice in the United Kingdom and chlorine would be readily inactivated under such conditions. Furthermore, soaking at $70^{\circ} \mathrm{C}$ would be too severe for the plastic material used in conventional UK crate manufacture - thermosetting plastic which is moulded with a multitude of ridges on a grid framework to provide sufficient reinforcing.

It is clearly possible to modify the existing cleaning process to reduce microbial contamination of the crates and the performance of options studied here would appear to compare favourably with suggestions, such as the use of disposable crate liners (Slader et al., 2002) and drying of cleaned crates before re-cycling them to eliminate Campylobacter (Berrang and Northcutt, 2005), both of which are likely to be costly. Not only would the latter require additional space at the plant for drying, but also investment in additional new crates to compensate for the delay in supplying those needed for immediate re-use (Burton et al., 2004).

Whatever the most effective changes to the system, a successful means of reducing microbial contamination of transport crates could contribute significantly to overall hygiene control in poultrymeat production and may also play a part in 
controlling some diseases that are of economic concern to the Industry. However, total elimination of pathogens on crates may not be possible and it is unclear if such a reduction will be effective in controlling a particular hazard.

Acknowledgement

The work described in this paper formed part of a project funded by the UK Food

Standards Agency. The authors are indebted to the management and technical staff of the poultry companies who collaborated in this research and to PLC Ltd for their advice and loan of the ultrasonic equipment.

\section{REFERENCES}

ALLEN, V.M., WEAVER, H., RIDLEY, A. M., HARRIS, J. A., SHARMA, M., EMERY, J., SPARKS, N., LEWIS, M. AND EDGE, S. (2008) Sources and

Deleted: In Press spread of thermophilic Campylobacter spp. during partial depopulation of broiler chicken flocks. Journal of Food Protection,

BAILEY, J.S., STERN, N.J., FEDORKA-CRAY, P., CRAVEN, S.E., COX, N.A., COSBY, D.E., LADELY, S. \& MUSGROVE, M.T. (2001) Sources and movement of Salmonella through integrated poultry operations: A multistate epidemiological investigation. Journal of Food Protection, 64: 1690 - 1697.

BERRANG, M.E. \& NORTHCUTT, J.K. (2005) Use of water spray and extended drying time to lower bacterial numbers on soiled flooring from broiler transport coops. Poultry Science, 84: $1797-1801$.

BURTON, C.H., WHYTE, R.T., ALLEN, V.M. CORRY, J.E.L. \& DAVIES, R. (2004) Reducing Microbial Contamination of Poultry Transport Crates by Improved Cleaning and Disinfection Systems Based on Better Water Use: A State-of-the-Art Report on Crate Washing. Silsoe, UK, Silsoe Research Institute. 
CARR, L., RIGAKOS, L., CARPENTER, G., BERNEY, G. \& JOSEPH, S. (1999) An assessment of livehaul poultry transport container decontamination. Dairy, Food \& Environmental Sanitation, 19: 753 - 759.

CORRY, J.E.L., ALLEN, V.M., HUDSON, W.R., BRESLIN, M.F. \& DAVIES, R.H. (2002) Sources of Salmonella on broiler carcasses during transportation and processing: modes of contamination and methods of control. Journal of Applied Microbiology, 92: $424-432$.

HUMPHREY, T.J. \& ALLEN, V.M. (2002) Poultry Crate Hygiene: Final Report (FSA Project ZB 00033). Bristol, UK, University of Bristol.

JACOBS-REITSMA, W.F. \& BOLDER, N. (1998) The role of transport crates in Campylobacter contamination of broilers, in: Lastovica, A.J., Newell, D.G \& Lastovica, E.E. (Eds) Campylobacter, Helicobacter and Related Organisms: Proceedings of the Ninth International Workshop pp. 379 - 380 (Capetown, S.A. Capetown Unversity).

RAMESH, N., JOSEPH, S.W., CARR, L.E., DOUGLASS, L.W. \& WHEATON, F.W. (2003) Serial disinfection with heat and chlorine to reduce microorganism populations on poultry transport containers. Journal of Food Protection, 66: 793 -797 .

RIGBY, C.E., PETTIT, J.R, BAKER, M.F., BENTLEY, A.H., SALOMENS, M.O. \& LIOR, H. (1980a) Sources of Salmonella in an uninfected commercially processed broiler flock. Canadian Journal of Comparative Medicine, 44: 267 274.

RIGBY, C.E., PETTIT, J.R, BAKER, M.F., BENTLEY, A.H., SALOMENS, M.O. \& LIOR, H. (1980b) Flock infection and transport as sources of salmonellae in 
351 352

broiler chickens and carcasses. Canadian Journal of Comparative Medicine, 44: $323-337$.

SLADER, J., DOMINGUE, G., JØRGENSEN, F., McAlPINE, K., OWEN, R.J., BOLTON, F.J. \& HUMPHREY, T.J. (2002) Impact of transport crate reuse and of catching and processing on Campylobacter and Salmonella contamination of broiler chickens. Applied and Environmental Microbiology, 68: 713 - 719.

TINKER, D.B., BURTON, C.H. \& ALLEN, V.M. (2005) Catching, transporting and lairage of live poultry, in: Mead, G.C. (Ed) Food Safety Control in the Poultry Industry pp. 153 - 173 (Cambridge, UK, Woodhead Publishing). 
360

Table 1. Microbiological examination of crates before and after factory cleaning at three different processing plants (all counts: mean $\log _{10}$ cfu per base, with standard deviation).

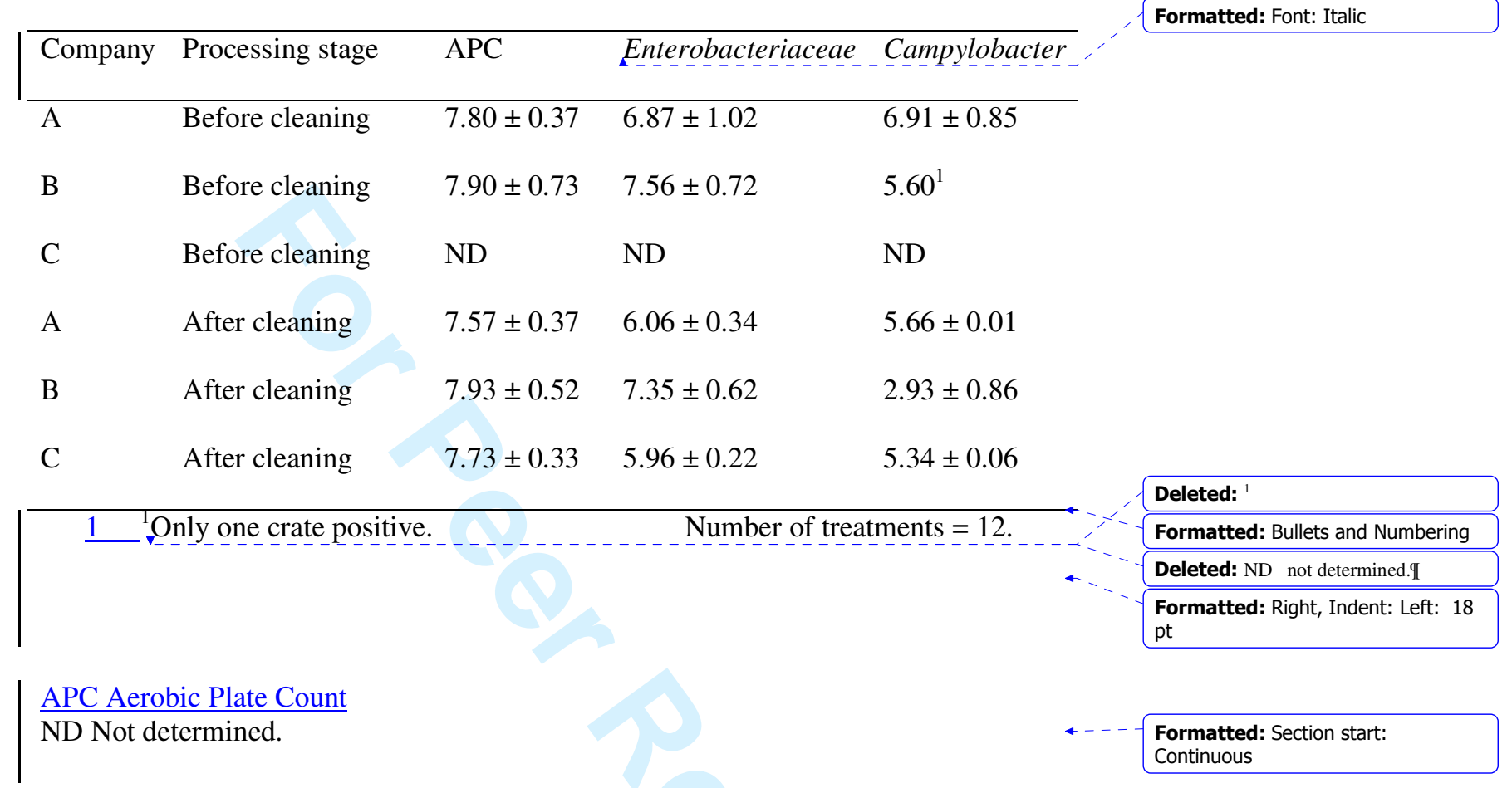


Table 2. Comparison of visual assessment of residual organic debris on cleaned crates with extent of microbial contamination.

\section{$\mathrm{APC}_{\Delta=}^{2}$ Enterobacteriaceae ${ }^{2}$}

\begin{tabular}{|llll}
\hline 1 & 3 & 8.10 & 6.70 \\
2 & $<1$ & 7.81 & 6.63 \\
3 & 2 & 7.81 & 6.33 \\
4 & 1 & 8.18 & 6.87 \\
5 & 8 & 8.02 & 6.67 \\
6 & $<1$ & 8.18 & 6.77 \\
7 & $<1$ & 8.04 & 6.62 \\
8 & 1 & 7.98 & 7.23 \\
9 & 2 & 8.60 & 6.85 \\
10 & 1 & 8.25 & 7.12 \\
11 & 1 & 7.98 & 6.82 \\
12 & $<1$ & 8.24 & 7.14 \\
\hline
\end{tabular}

${ }^{\mathrm{T}}$ Weight $(\mathrm{g})$ of material per crate base.

${ }^{2} \log _{10}$ cfu per crate base. 
367

368

Changes in the relative aerobic plate counts and Enterobacteriaceae jn preliminary trials using different treatments tested using the

Table 3. experimental rig.

\begin{tabular}{|c|c|c|c|}
\hline \multirow[t]{2}{*}{ Code } & \multirow[t]{2}{*}{ Description of treatment } & \multicolumn{2}{|c|}{$\begin{array}{l}\text { Change in count relative } \\
\text { to uncleaned control }\end{array}$} \\
\hline & & APC & $\begin{array}{c}\text { Enterobact- } \\
\text { eriaceae. }\end{array}$ \\
\hline$\overline{\mathrm{SWC}}$ & $15 \mathrm{~s}$ pre-wash, $30 \mathrm{~s}$ soak, $15 \mathrm{~s}$ main wash (standard clean control) & +0.2 & +0.5 \\
\hline TA3 & No pre-wash, $30 \mathrm{~s}$ soak, $300 \mathrm{~s}$ main wash & -1.0 & -1.8 \\
\hline TA4 & $300 \mathrm{~s}$ pre-wash, $30 \mathrm{~s}$ soak, $300 \mathrm{~s}$ main wash & -0.8 & -1.8 \\
\hline TA5 & $15 \mathrm{~s}$ pre-wash, $300 \mathrm{~s}$ soak $\left(40^{\circ} \mathrm{C}\right), 15 \mathrm{~s}$ main wash & -0.6 & -1.1 \\
\hline TA7 & $15 \mathrm{~s}$ pre-wash, $300 \mathrm{~s}$ soak $\left(60^{\circ} \mathrm{C}\right), 15 \mathrm{~s}$ main wash & -1.6 & -1.5 \\
\hline
\end{tabular}

Deleted: Results of

Formatted: Font: Italic

Deleted:

Deleted: $o n$

Deleted: in 


\section{Page 19 of 24}

\section{British Poultry Science}

TB8 $15 \mathrm{~s}$ pre-wash, $30 \mathrm{~s}$ soak, $15 \mathrm{~s}$ vibration, $60 \mathrm{~s}$ air-dry, $15 \mathrm{~s}$ wash $\left(60^{\circ} \mathrm{C}\right)$

TC1 $15 \mathrm{~s}$ pre-wash, $30 \mathrm{~s}$ soak, $15 \mathrm{~s}$ main wash, $15 \mathrm{~s}$ wash with clean water $\left(60^{\circ} \mathrm{C}\right), 60 \mathrm{~s}$ air-dry, $60 \mathrm{~s}$ exposure to UV

TC2 $15 \mathrm{~s}$ pre-wash, $30 \mathrm{~s}$ soak, $15 \mathrm{~s}$ main wash, $15 \mathrm{~s}$ wash with clean water $\left(60^{\circ} \mathrm{C}\right), 120 \mathrm{~s}$ steam

TC3 $15 \mathrm{~s}$ pre-wash, $30 \mathrm{~s}$ soak, $15 \mathrm{~s}$ main wash, $15 \mathrm{~s}$ wash with clean water $\left(60^{\circ} \mathrm{C}\right), 250 \mathrm{ml} 0.5 \%$ Virkon $\mathrm{S}$

TC4 $15 \mathrm{~s}$ pre-wash, $30 \mathrm{~s}$ soak, $15 \mathrm{~s}$ main wash, $15 \mathrm{~s}$ wash with clean water $\left(60^{\circ} \mathrm{C}\right), 60 \mathrm{~s}$ air-dry, $250 \mathrm{ml} 0.5 \%$ Virkon S

TC5 $15 \mathrm{~s}$ pre-wash, $30 \mathrm{~s}$ soak, $15 \mathrm{~s}$ main wash, $15 \mathrm{~s}$ wash with clean water, $60 \mathrm{~s}$ air-dry, $250 \mathrm{ml} 0.5 \%$ Virkon S 
TD3 $15 \mathrm{~s}$ pre-wash, $30 \mathrm{~s}$ soak, $15 \mathrm{~s}$ main wash $\left(63^{\circ} \mathrm{C}\right), 500 \mathrm{ml} 2 \%$ Virkon $\mathrm{S}$

TD4 $15 \mathrm{~s}$ pre-wash, $30 \mathrm{~s}$ soak, $120 \mathrm{~s}$ brush, $15 \mathrm{~s}$ main wash $\left(63^{\circ} \mathrm{C}\right), 500 \mathrm{ml} 2 \%$ Virkon S

TD5 $15 \mathrm{~s}$ pre-wash, $30 \mathrm{~s}$ dirty-water soak $\left(55-60^{\circ} \mathrm{C}\right), 15 \mathrm{~s}$ clean wash $\left(63^{\circ} \mathrm{C}\right)$

TD6 $15 \mathrm{~s}$ pre-wash, $30 \mathrm{~s}$ soak in clean water with $0.1 \%$ detergent $\left(55-60^{\circ} \mathrm{C}\right), 15 \mathrm{~s}$ clean wash $\left(63^{\circ} \mathrm{C}\right)$

TD7 $15 \mathrm{~s}$ pre-wash, $30 \mathrm{~s}$ soak in clean water with $0.1 \%$ detergent $\left(55-60^{\circ} \mathrm{C}\right), 15 \mathrm{~s}$ clean wash $\left(63^{\circ} \mathrm{C}\right)$, wash repeated

${ }^{1}$ Based on a comparison of mean counts.

Number of treatments $=5$.

Soaking and washing were in cold water unless stated otherwise. 
Figure 1. The test rig set up on a trailer to enable periodic use in the lairage/crate washing areas of the processing plant.

Figure 2. Schematic diagram of the test rig, showing the basic components.

Figure 3. Effects on microbial contamination of crate treatments selected from preliminary trials: (a) aerobic plate counts; (b) Enterobacteriaceae; (c) Campylobacter.

\begin{tabular}{|c|c|}
\hline Key & P \\
\hline \multicolumn{2}{|l|}{ Before } \\
\hline cleaning & Freshly-emptied crates \\
\hline $\begin{array}{l}\text { Standard } \\
\text { clean }\end{array}$ & $15 \mathrm{~s}$ pre-wash, $30 \mathrm{~s}$ soak and $15 \mathrm{~s}$ wash in dirty water \\
\hline TE1 & $15 \mathrm{~s}$ pre-wash, $30 \mathrm{~s}$ soak, $90 \mathrm{~s}$ brush, $15 \mathrm{~s}$ wash with clean water $90 \mathrm{~s}$ brush \\
\hline \multirow{3}{*}{ TE2 } & $15 \mathrm{~s}$ pre-wash, $30 \mathrm{~s}$ soak $\left(55^{\circ} \mathrm{C}\right)$ with $0.1 \%$ detergent, $90 \mathrm{~s}$ brush, \\
\hline & $15 \mathrm{~s}$ wash in clean water $\left(60^{\circ} \mathrm{C}\right)$; soak, brush and wash repeated; $500 \mathrm{ml} 2 \%$ \\
\hline & 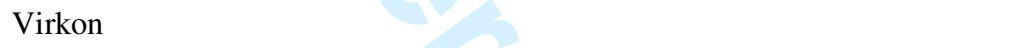 \\
\hline TE3 & $\begin{array}{l}15 \mathrm{~s} \text { pre-wash, } 30 \mathrm{~s} \text { soak }\left(55^{\circ} \mathrm{C}\right) \text { with } 0.1 \% \text { detergent, } 90 \mathrm{~s} \text { brush, } \\
15 \mathrm{~s} \text { wash in clean water }\left(60^{\circ} \mathrm{C}\right), 500 \mathrm{ml} 2 \% \text { Virkon }\end{array}$ \\
\hline TE4 & $\begin{array}{l}15 \mathrm{~s} \text { pre-wash, } 30 \mathrm{~s} \text { soak }\left(55^{\circ} \mathrm{C}\right) \text { with } 0.1 \% \text { detergent, } \\
15 \mathrm{~s} \text { wash in clean water }\left(60^{\circ} \mathrm{C}\right), 500 \mathrm{ml} 2 \% \text { Virkon }\end{array}$ \\
\hline TE5 & Standard clean, $500 \mathrm{ml} 2 \%$ Virkon \\
\hline TE6 & Standard clean, $30 \mathrm{~s}$ brush, 3 min ultrasound $\left(65^{\circ} \mathrm{C}\right)$ \\
\hline TE7 & Standard clean, $30 \mathrm{~s}$ brush, 6 min ultrasound $\left(65^{\circ} \mathrm{C}\right)$ \\
\hline TE8 & Standard clean, 6 min ultrasound $\left(65^{\circ} \mathrm{C}\right)$ \\
\hline $\mathrm{n}=$ & treatments \\
\hline
\end{tabular}




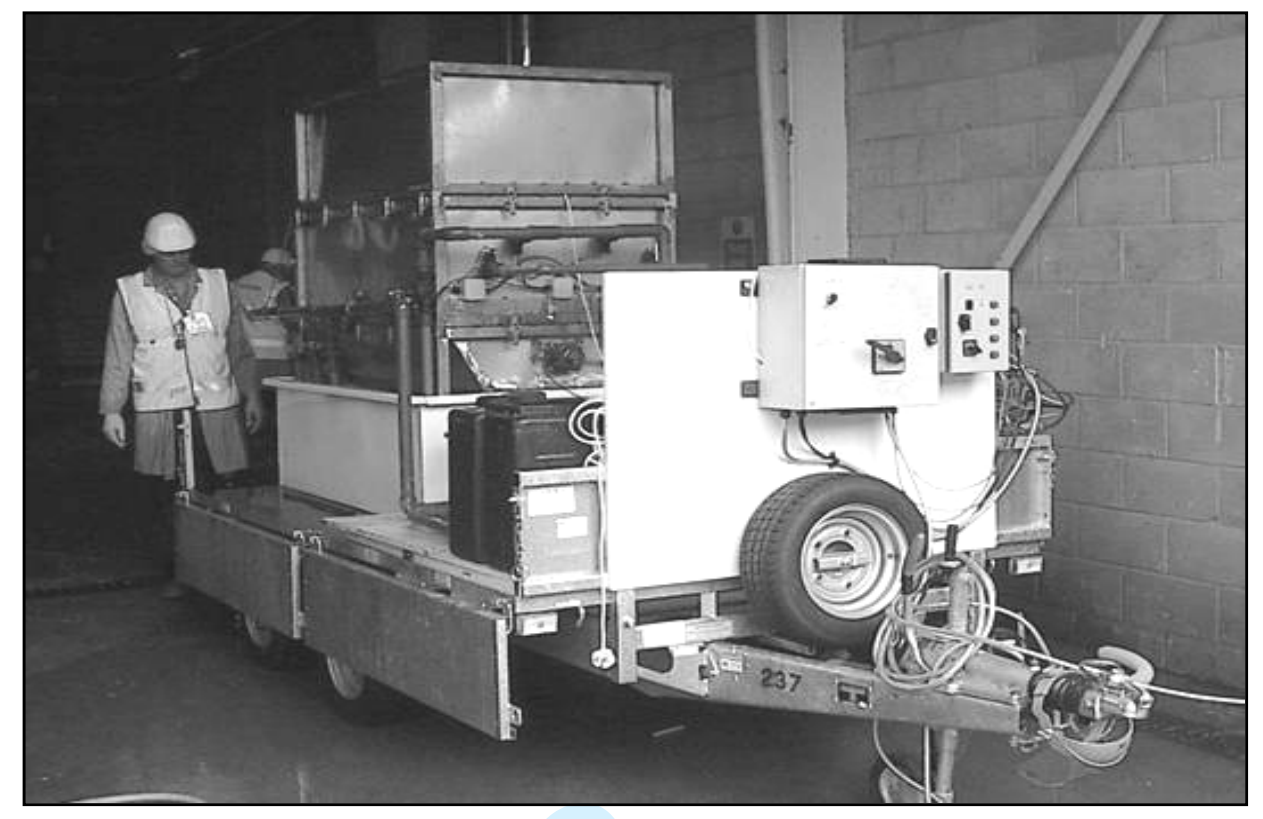

Figure 1 


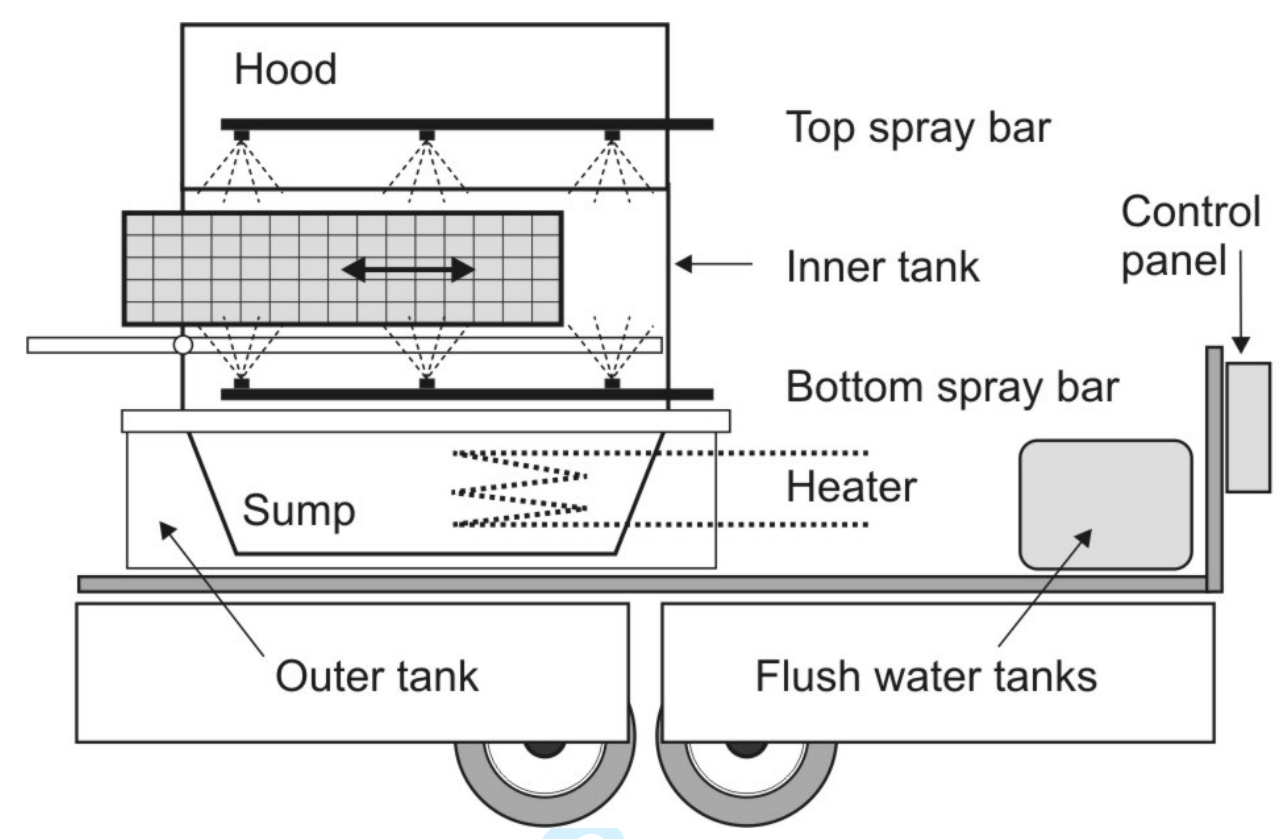

Figure 2 
1

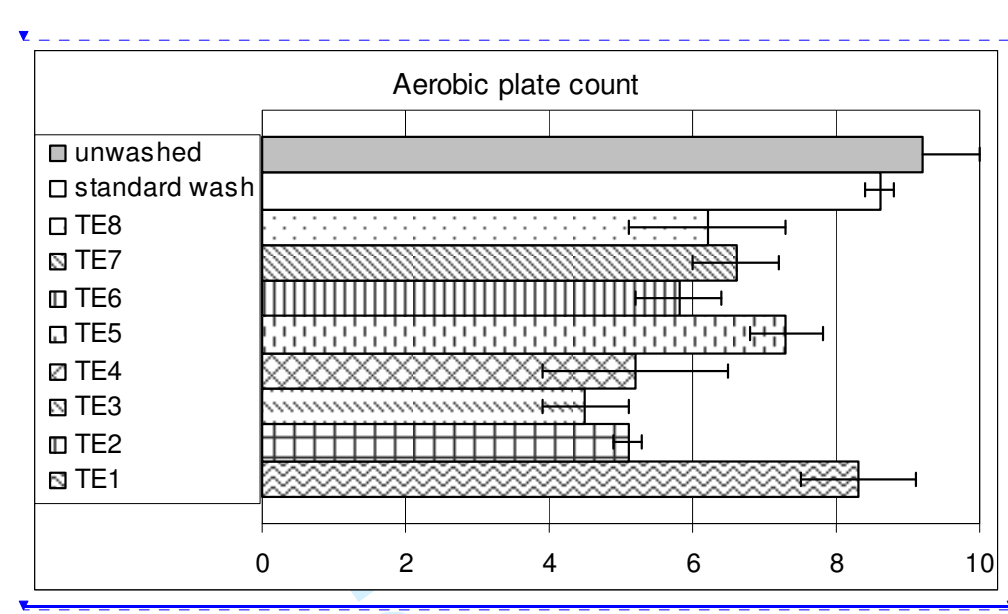

Log $_{10}$ CFU per crate base

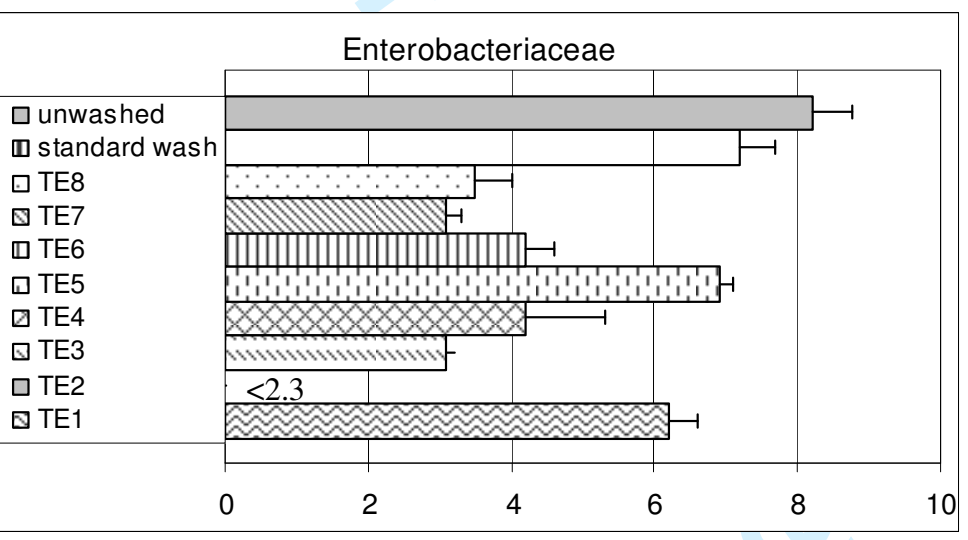

$\underline{\log _{10}} \underline{C F U} \underline{\text { per crate base }}$

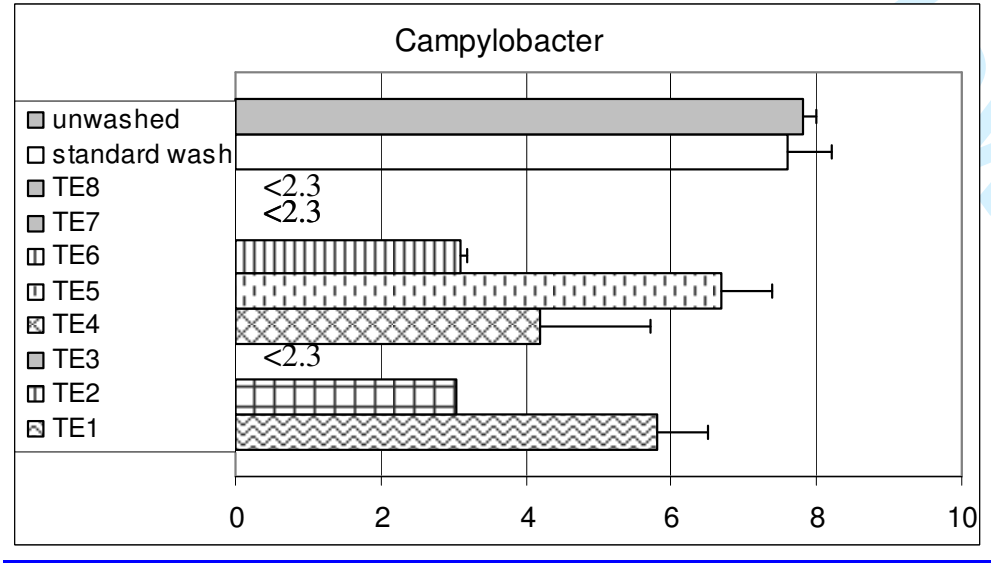

$\underline{\log _{10}} \underline{\text { CFU }} \underline{\text { per crate base }}$

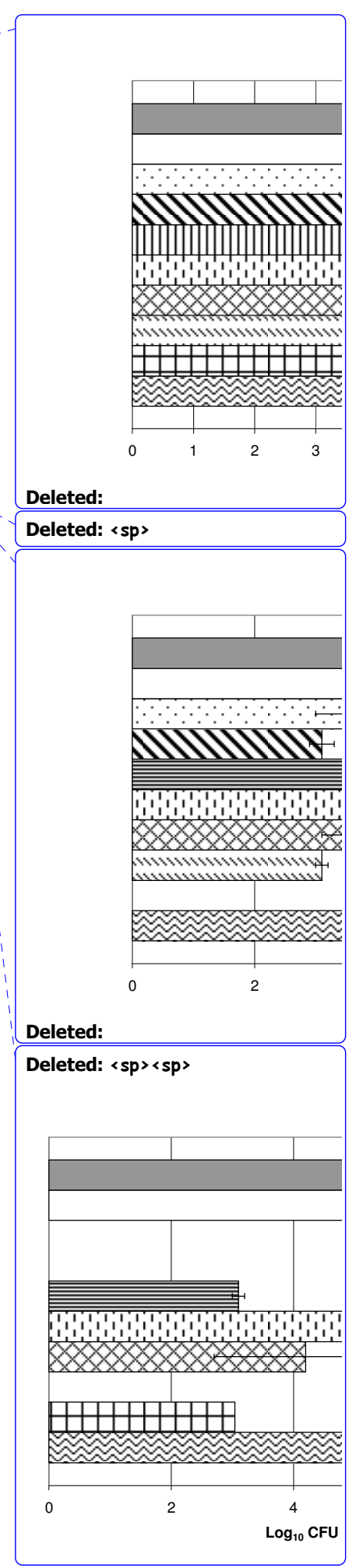

Figure 3 